\section{Healthy food and its influence on consumption: Explicit and implicit attitudes}

\title{
Abstract
}

Introduction: Food choice is influenced by several factors, including intrinsic and extrinsic food characteristics. Nutritional food properties, and, the health benefits provided by these, may affect this choice.

Objective: The aim of this study was to evaluate the influence of health allegations on food choices of adults explicitly and implicitly, by adapting the Implicit Association methodology.

Method: The sample consisted in 108 individuals. For explicit assessment, the sensory acceptability analysis test was conducted in two sessions (blind and with information), to evaluate the influence of non-sensory characteristics. For implicit assessment, an implicit test was performed, using FreelAT software. To evaluate nutritional status, weight, height, and waist circumference were measured and Body Mass Index calculated. To analyze the results, descriptive statistics were performed to observe the frequency, the mean \pm standard deviation. In, addition, the t-test and Spearman correlation test were performed, adopting a $5 \%$ significance level.

Results: In the explicit evaluation, it was observed that information about health benefits positively influenced food choice $(p<0.01)$. When assessing healthy food information implicitly, it was clear that $43,52 \%$ of participants had a strong preference for healthy foods.

Conclusion: The results showed that knowledge about the nutritional aspects of food interferes with food choices explicitly and implicitly. Also, the FreelAT program proved to be an excellent complementary tool for studies, with consumers regarding food choices, being an innovation for researches in this segment.

Jamille Marinho Brazil ${ }^{1}$ Maria Patrícia Milagres², Evely Rocha Lima3, Cláudia Fabiana Brazil Pinto ${ }^{4}$, Gesivaldo Santos ${ }^{5}$, Willian de Bulhões Brandão ${ }^{6}$, Ramon Araujo dos Santos 7 , Rafael Pereira ${ }^{8}$, Valdiney Veloso Gouveia $^{9}$

1 Master in Health Sciences. Estate University of Southwest Bahia. Jequié, Bahia, Brazil. E-mail: jamille.marinho@ hotmail.com, corresponding author.

$2 \mathrm{PhD}$ in Food Science and Technology. Estate University of Southwest Bahia. Jequié, Bahia, Brazil.

3 Undergraduate Pharmacy. Estate University of Southwest Bahia. Jequié, Bahia, Brazil.

4 Master in dentistry. Estate University of Southwest Bahia. Jequié, Bahia, Brazil.

$5 \mathrm{PhD}$ in Functional and Molecular Biology. Estate University of Southwest Bahia. Jequié, Bahia, Brazil.

6 Master in Natural Products Pharmacology. Estate University of Southwest Bahia. Jequié, Bahia, Brazil.

7 Postgraduate program (scrito sensu) in Engineering and Food Science. Estate University of Southwest Bahia. Itapetinga, Bahia, Brazil.

$8 \mathrm{PhD}$ in Biomedical Engineering. Estate University of Southwest Bahia. Jequié, Bahia, Brazil.

9 Phd in Social Psychology. Federal University of Paraiba. João Pessoa, Paraíba, Brazil.

Contact information:

Jamille Marinho Brazil

झ jamille.marinho@hotmail.com

Keywords

Implicit association; explicit measure; food choice; healthy eating. 


\section{Introduction}

Diet plays a crucial role in life quality and people's well-being, also acting in the prevention and control of diseases. Consumption of healthy food, such as foods rich in vitamins, minerals, dietary fibers, and poly- and monounsaturated fats help prevent hyperlipidemia, obesity, and diabetes mellitus, as these influence the lipid profile, controlling body weight and glycemia ${ }^{(1)}$.

However, the act of feeding oneself transcends biological reasons, because food has several meanings, including social, economic, and cultural. Numerous factors influence food choices, such as the sensory properties (evaluated by the senses, such as taste, smell, sight, and touch), which comprise intrinsic aspects of food (odor, flavor, appearance, texture, and others). Also, the aspects extrinsic to food, such as economic issues (price, income, and advertising), health and nutrition (prevention or control of diseases), and family eating habits (cultural), also influence food choices ${ }^{(2)}$.

Given the many factors affecting food choice, studies to define the aspects that influence buying decisions are increasingly complex. Traditional sensory food analysis, which evaluates only intrinsic factors, is insufficient to ensure that the product being developed meets consumer expectations. Thus, new methods have been developed for consumer studies, such as the Conjoint Analysis ${ }^{(3)}$, the Principal Component Analysis with the Preference Map technique ${ }^{(4)}$, to test the application of methodology of sensory acceptance test in sessions to evaluate non-sensory characteristics ${ }^{(5)}$

However, new methodologies for consumer studies measure only the explicit attitude of the individual, be it conscious, controlled, or reflective. The question is to what extent that attitude is real or feigned, because the consumer can mask acceptance or rejection of the product. This calculated behavior may be due to some constraint or even to be accepted in society.
In this context, it is essential to develop study methods with consumers already using implicit measures, besides the explicit measures already practiced. This implicit tool will allow researchers to obtain more reliable information about food from consumers.

The implicit attitude has been studied by social psychologists, who, increasingly, have devoted attention to automatic processes in understanding social and behavioral trials. Therefore, when trying to understand the attitudes, decisions, emotions, and motives of consumers, unconscious to automatic processes should be considered $(6,7,8,9,10)$.

To evaluate unconscious human behavior, Greenwald, McGhee and Schwartz (1998) ${ }^{(11)}$ developed the Implicit Association Test (IAT). Since then, the IAT has been used in various fields of study, such as implicit attitude toward smoking among children ${ }^{(12)}$, mediating expectations about alcohol(13), measuring attitudes and behavior of consumers concerning food brands, restaurants and drinks ${ }^{(14)}$,evaluating implicit attitudes towards poliamory ${ }^{(15)}$ and others. However, there was no application of this tool related to health and food choice.

The IAT involves a computerized device on which the participant is asked to associate items/stimuli (words or images) displayed in the center of the computer screen with categories (words) that appear on the top side of the screen. To associate the stimulus with the category on the left, the participant should hit the key " $E$ ", and to associate it with the category on the right one must hit the key "I". It is important that the participant makes this association as quickly as possible and makes as few mistakes as possible, because this technique evaluates response time to stimuli in milliseconds ${ }^{(16)}$.

From the values of the response time of the participants, it is possible to calculate the conventional D Score, which measures the implied association ${ }^{(11)}$. Owing to the variability in scores from the difference in test performance ability, it was developed the D-Score (GNB Score), which is the result of the 
difference between the incongruent and congruent blocks (conventional score) divided by the standard deviation of the participant of all latencies of responses, in the two blocks.

A new alternative to the use of implicit association is the FreelAT program, which is available free of charge, easy to handle and available in Portuguese. This program allows the inclusion of stimuli chosen by the researcher, which will depend on the subject matter. In addition to providing the response time of each participant, the average response time, standard deviation, other values, and especially the D score, value required to evaluate possible associations ${ }^{(15)}$.

Given the above, the aim of this study was to assess the influence of the health allegation in adult food choices explicit and implicitly, by adapting the Implicit Association methodology for studies on food and health.

\section{Methods}

This is a quantitative study of exploratory and transversal character.

\section{Ethical approval}

This study was approved by the Ethics Committee of the State University of Southwest Bahia, according to protocol 274.122, taking into account the Resolution No. 466, of December 12, 2012, from the National Council of health ${ }^{(18)}$. Data collection only started after the approval of the project and after reading and signing a Free Consent Term and Clarification by the research participants. All participants were informed about the survey and invited to participate voluntarily.

\section{Study participants and local}

Participated in this study were 108 individuals participated. Participants were teachers, employees and students of the State University of Southwest Bahia (UESB), aged between 18 and 38 years. The sample was defined by convenience (non-probabilistic, intentional).
People with physical disabilities that were not able to makefast hand movements were excluded, as were smokers, people with mental disabilities, illiterate people, pregnant women, those with colds, denture prosthesis users and/or those with any complications in the oral cavity that could influence the perception of taste.

The research was conducted in the laboratory of foods from UESB, Jequié campus, Bahia.

Personal information, socio-demographic features and attitudes were collected.

A structured questionnaire was applied to 108 participants, which required some personal information (name, address, and telephone number) to keep up with them during data collection. Questions about socio-demographic characteristics and attitudes (gender, age, race/color, marital status, education, religion, family income, physical activity) were included.

\section{Explicit test}

For the explicit evaluation, 108 participants were recruited, and the sensory acceptance test was performed in two sessions, aiming to evaluate the influence of non-sensory characteristics. The first session was the blind test, in which food was served without any information about it; there was only the description of the food (name), and samples were encoded with random numbers with three digits. In the second session, information was provided, so at that moment, the food was served with the information of the health benefits provided by it.

The food used in the test was dehydrated apricot, in compliance with the standardized sample size of 20 grams, which was served monodically in $50 \mathrm{ml}$ disposable cups. The test was performed in individual cabins to prevent communication among participants, under white light and in an acclimatized environment. Along with the samples, they were given a nine-point hedonic scale form19 for product evaluation, and water, for residual food taste removal between sessions. 
Data from the hedonic scale were nominal, ranging from disliked extremely to liked extremely. To facilitate understanding of these data, they have been transformed into numeric, scores from 1 to 9 , which were organized in two blocks: an accepting block, in which the scores ranged from 6 to 9; and a rejecting block, in which scores ranged from 1 to 5 came to their minds $(19,20)$.

\section{Implicit test}

The same 108 volunteers who participated in the explicit test, participated in the implicit test. The implicit assessment was conducted in the FreelAT program, Portuguese version(15), with easy installation and management, and the configuration was set up for this search. The title of the text was Food and Health. The first two categories were Healthy and not Healthy, which followed by the registration of positive and negative stimuli. The other categories were Pleasant and Unpleasant, registered as positive and negative stimuli.

After including the words used in the test, the quantity of trials of each block was set up. It followed the number of 20 attempts in the training blocks (1, 2 and 4) and 60 attempts in association tests (3 and 5$)^{(22,23)}$. In training block 1 , the word Healthy appeared as a category on the right and the word Not Healthy appeared as a category on the left; the stimulus appeared monodically in the center of the screen. In block 2, the category that appeared on the right was Pleasant and the category on the left was Unpleasant. Again, the stimulus appeared in the center of the screen. In block 3 of associations, categories appear in combination, given that on the right appeared Healthy/Pleasant and on the left appeared Unhealthy/Unpleasant. Therefore, the stimulus appeared in the center of the screen once more. In block 4, the category Unhealthy appeared on the right, and the category Healthy appeared on the left. In block 5, new associations were created, in which Unhealthy/Pleasant appeared on the right, and Healthy/Unpleasant appeared on the left.

\section{Nutritional Assessment}

A nutritional status assessment was performed for all 108 participants in the explicit and implicit tests. Weight, height, and waist circumference (WC) was measured. Body Mass Index (BMI) was calculated and classified according to the World Health Organization (WHO), as well as the WC, compliant with the WHO criterion (24)

\section{Statistical Analysis}

Statistical analysis was performed using the statistical software Statistical Package for Social Sciences (SPSS) version 21.0.

The described statistics were used to characterize the socio-demographic data and attitudes of the 108 participants from explicit and implicit tests, and nutritional assessment, using the frequency of each variable.

Data obtained from the explicit test were analyzed through descriptive statistics to observe frequencies, mean and standard deviation of scores obtained for the dehydrated apricot in the blind test and test with information. Also, the $t$-test for paired samples was conducted to evaluate the influence of health benefit information on consumer acceptance. A 5\% significance level was adopted.

To assess the strength of association of the implicit measure, the score $D$ results were in five groups. The first group comprised the values below 0 (opposite attitude for healthy food); the second group, values from 0 to 0.15 (there is no clear preference); the third group, values from 0.16 to 0.35 (weak association); the fourth group, values from 0.36 to 0.65 (moderate preference); and, finally, the fifth group, values over 0.65 (strong preference) $)^{(22,25)}$.

After this categorization, descriptive statistics was used to observe the frequency of values obtained in FreelAT.

The correlations from socio-demographic data and attitudes, from explicit and implicit measures, and from nutritional assessment were performed by 
the Spearman correlation coefficient. The level of significance used for analyses was $5 \%$.

\section{Results}

The study population was homogeneous regarding sex: $48.10 \%$ were men $(n=52)$ and $51.90 \%$ women $(n=56)$. Most participants were between 18 and 28 years old $(88.00 \%, n=95)$, as described in Table 1. In addition, The educational level of the sample was high, with $91.70 \%(n=99)$ having attended or attending a graduate school.

As described in Table 2, the information of health benefits from apricot positively influences the acceptance of the product. In the blind test, $30.60 \%$ ( $n=33$ ) of participants rejected the food (scores 1 to 5 ), after the benefits information, only $23.10 \%$ ( $n=30$ ) were still rejecting it. Furthermore, the mean score increased over sessions. In the blind test, the mean of the scores obtained was 6.20 ( \pm 1.85) and in the test with information was 6.57 ( \pm 1.90), reaching a significant difference between the measurements $(p<0.01)$.

In the implicit test, the value of the categorized Score $D^{(22,25)}$ revealed that $33.33 \%(n=36)$ of participants had a moderate preference (0.36 to 0.65 ) for healthy food, assigning positive words to this group, and $43.52 \%(n=47)$ of participants had a strong preference (over 0.65) for healthy food, as described in Table 3.

In relation to the age, it was observed that it influences the choice of healthy foods, and a positive correlation between age and preference for healthy food was impliedly observed ( $p<0.05$ ) as shown in Table 4.

\section{Discussions}

In this study, the educational level of the sample was high. This finding may be explained by the research environment, which was a university. Contributing to this study, research conducted in a University reveals that $80.00 \%(n=80)$ of participants wereattending at leasta graduate program $^{(26)}$.
Table 1. Socio-demographic characteristics and attitudes of 108 participants from explicit and implicit tests, and nutritional assessment.

\begin{tabular}{|c|c|c|}
\hline Variable & $\mathbf{N}$ & $\%$ \\
\hline \multicolumn{3}{|l|}{ Sex } \\
\hline Male & 52 & 48.10 \\
\hline Female & 56 & 51.90 \\
\hline \multicolumn{3}{|l|}{ Age (Years) } \\
\hline $18-28$ & 95 & 87.90 \\
\hline $29-38$ & 13 & 12.10 \\
\hline \multicolumn{3}{|l|}{ Race } \\
\hline Yellow & 2 & 1.90 \\
\hline White & 23 & 21.30 \\
\hline Mixed & 55 & 50.90 \\
\hline Black & 28 & 25.90 \\
\hline \multicolumn{3}{|l|}{ Marital Status } \\
\hline Nopartner & 101 & 93.50 \\
\hline With partner & 7 & 6.50 \\
\hline \multicolumn{3}{|l|}{ Education } \\
\hline Elementary & 1 & 0.90 \\
\hline High School & 8 & 7.40 \\
\hline Some college & 68 & 63.00 \\
\hline Undergraduate degree & 19 & 17.60 \\
\hline Graduate degree & 12 & 11.10 \\
\hline \multicolumn{3}{|l|}{ Family Monthly Income } \\
\hline Up to $R \$ 724.00$ & 12 & 11.10 \\
\hline$R \$ 724.00-R \$ 1,500.00$ & 33 & 30.60 \\
\hline$R \$ 1,500.00-R \$ 3,000.00$ & 36 & 33.30 \\
\hline$R \$ 3,000.00 R \$ 5,000.00$ & 14 & 13.00 \\
\hline $\begin{array}{l}\text { More than } \mathrm{R} \$ 5,000.00 \\
\text { Physical Activity }\end{array}$ & 13 & 12.00 \\
\hline $\begin{array}{l}\text { Physical Activity } \\
\text { Yes }\end{array}$ & 57 & 52.80 \\
\hline No & 51 & 47.20 \\
\hline \multicolumn{3}{|l|}{ Religion } \\
\hline Catholic & 44 & 40.70 \\
\hline Protestant & 39 & 36.10 \\
\hline Adventist & 4 & 3.70 \\
\hline Spiritist & 21 & 19.40 \\
\hline
\end{tabular}

The information of health benefits from apricot positively influences the acceptance of the food. In the blind test, the mean of the scores obtained was $6.20( \pm 1.85)$ and in the test with information was $6,57( \pm 1,90)$, reaching a significant difference between the measurements. Studies performed on the influence of health benefits information on food 
Table 2. Frequency, mean and standard deviation of the scores obtained for dehydrated apricot between sessions.

\begin{tabular}{|c|c|c|c|c|c|c|c|c|c|c|c|}
\hline \multirow{2}{*}{ Food } & \multirow{2}{*}{ Test type } & \multicolumn{9}{|c|}{ Scores (\%) } & \multirow{2}{*}{ Mean ( \pm SD) } \\
\hline & & 1 & 2 & 3 & 4 & 5 & 6 & 7 & 8 & 9 & \\
\hline \multirow{2}{*}{ Apricot } & Blind Test & 1.9 & 2.8 & 4.6 & 6.5 & 14.8 & 21.3 & 23.1 & 15.7 & 9.3 & $6.20( \pm 1.85) \mathrm{A}$ \\
\hline & $\begin{array}{l}\text { Test with } \\
\text { information }\end{array}$ & 0.9 & 3.7 & 4.6 & 4.6 & 9.3 & 17.6 & 24.1 & 20.4 & 14.8 & $6.57( \pm 1.90) B$ \\
\hline
\end{tabular}

${ }^{*}$ )Different letters indicate significant differences between the means involved, the significancelevel is 5\% (t-Test).

Table 3. Frequency of values of categorized Score D, FreelAT.

\begin{tabular}{|c|c|c|c|}
\hline Categorized Score D & Description & Frequency (\%) & Frequency $(\mathbf{n})$ \\
\hline$<0$ & Contrary attitude to the research object & 10.18 & 11 \\
\hline $0-0.15$ & There is no clear preference & 4.64 & 5 \\
\hline $0.16-0.35$ & Weak association & 8.33 & 9 \\
\hline $0.36-0.65$ & Moderate preference & 33.33 & 36 \\
\hline$>0.65$ & Strong preference & 43.52 & 47 \\
\hline
\end{tabular}

choices have shown that this information positively influences the acceptance of food $(5,27)$.

Corroborating the above statement, study by performing the acceptance test in sessions, to evaluate the influence of health benefits information in exotic fruit juices, it was observed that the information positively influenced acceptance thereof (5). Similar results were found for milk with a high concentration of melatonin, both the information of the presence of such substance and the benefits from it influenced positively in the acceptance of the product ${ }^{(27)}$.

According to Viana (2002), balanced diet is associated with healthy lifestyle in all age groups. Thereby, individuals engage in health-promoting behaviors, with the choice of healthy foods to prevent diseases or to control chronic or acute diseases(28).
However, studies on the behavior of individuals regarding healthy food choices only evaluate the conscious and controlled response with the aid of the explicit test. However, the question is how much this explicit measure is reliable. During the test, the participant can control their reactions and expose what they consider favorable. In this way, one can hide one's true preferences, expressing what would be accepted by society. Therefore, the implicit measure is important to avoid possible biases, since it evaluates the uncontrolled and unconscious respon$\mathrm{se}^{(29)}$.

The implicit measure was assessed by FreelAT(15), adapted for research on food and health. By using the FreelAT test as a complementary tool for studies with consumers about healthy food, it was remarkable that they prefer healthy foods implicitly. With 
Table 4. Correlations between attitude and socio-demographic data, explicit and implicit measure, and nutritional status.

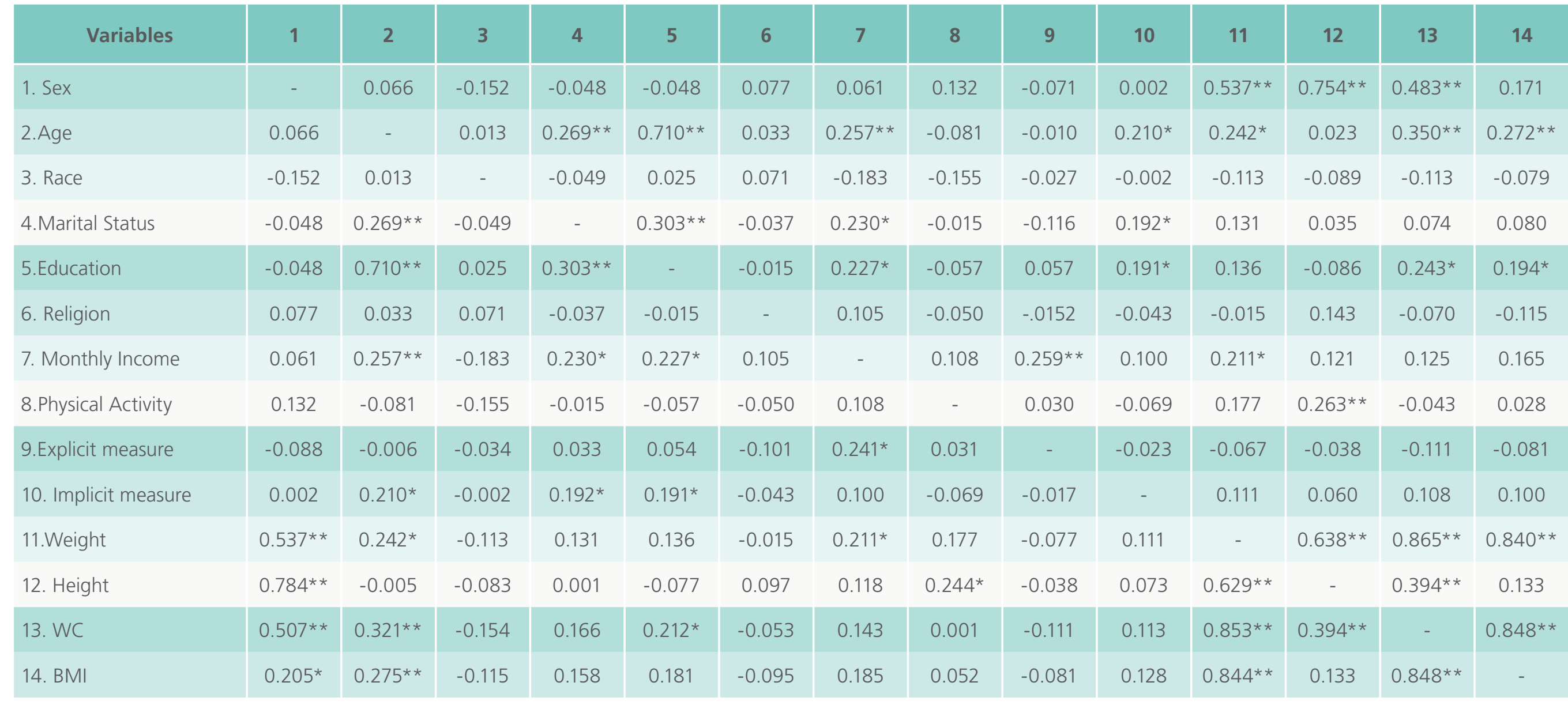

* Correlation is significant at the 0.05 level; ** Correlation is significant at the 0.01 level (Spearman) 
the explicit test, it was noticeable that, after the information of health benefits provided by food, consumers start to accept more such products.

Healthy eating habits are a fundamental requirement for health promotion and disease prevention. Furthermore, it enables the growth, development and maintenance of the human body with life quality. The choice of unhealthy foods is associated with an increase in non-communicable chronic diseases, such as obesity, high blood pressure, diabetes and others(30).

From this perspective, young adult consumers in this study prefer the consumption of healthy foods by explicit and implicit attitudes. In contrast to this finding, Barreto, Steps and Giatti (2009) studied the healthy behavior of young people (18 to 29 years old) and found that the consumption of healthy foods was low ${ }^{(31)}$. So, what distinguishes this study from others is the use of an implicit measure, which ultimately mitigated the limitations of explicit measures and minimized bias.

In this study, it was observed that the age of the individual influences preference for healthy foods, and a positive correlation between age and preference for healthy foods was observed implicitly $(p<0.05)$. Healthy food consumption is related to disease prevention, longevity, health promotion, and quality of life, which means, with healthy aging(32).

Given consumer concerns regarding food and health, they have sought information about food and the allegation of health benefits, aiming to improve life quality. Therefore, the food industry has invested in the production of foods with health allegations to reach the public(33)

In industrialized foods, nutrition labeling is an important tool to assist consumers in making healthier choices. However, consumers report difficulties with interpreting and applying the information printed on the labels ${ }^{(34)}$. Furthermore, research conducted to ascertain the information on the labels of food products, according to the legislation, eventually revealed many irregularities, further hindering consumer choice ${ }^{(35,36)}$.

\section{Conclusion}

Owing to consumer concerns regarding health, healthy eating has gained ground. Allegations of healthy foods and health benefits provided by foods positively influence acceptance explicitly, rationally, consciously and implicitly, that is, the automatic unconscious processes.

The FreelAT program showed itself to be an excellent complementary tool for studies with consumers about food choices, and an innovation for work in this field.

Also, knowledge about the nutritional aspects of food interferes with the food choices of individuals. Therefore, this factor of choice directly reflects on population health. It is thus essential to monitor, and reformulate printed information in food labeling, thereby corroborating healthy and conscious choices.

\section{Competing interests}

The authors declare that they have no competing interests.

\section{Funding}

The author's thanks the Foundation for Research Support of the State of Bahia for the granting of a Masters Scholarship and the National Council for Scientific and Technological Development for financial support.

\section{Abbreviations}

WC - Waist Circumference

IAT - Implicit Association Test

BMI - Body Mass Index

OPD - Optimized Profile Description

WHO - World Health Organization

SPSS - Statistical Package for Social Sciences

UESB - State University of Bahia Southwest

\section{Contribution of the authors}

JMB participated in the conception and design of 
the study, contributed scientifically and intellectually for the execution of the study, performed data collection, statistical analysis and interpretation of results, in addition to writing the manuscript. MPM, ERL, CFBP, GS, WBB, RAS, RP and VVG participated in the conception and design of the study, contributed scientifically and intellectually for the execution of the study, critical review, and final approval.

\section{References}

1. Fedirko V, Lukanova A, Bamia C, Trichopolou A, Trepo E, NöthlingsU.Glycemic index, glycemic load, dietary carbohydrate, and dietary fiber intake and risk of liver and biliary tract cancers in Western Europeans. Annals of Oncology.[Internet]. 2013. [cited 2014 dec 02];24:543-553. Available from:<http:// www.researchgate.net/publication/232812131_Glycemic_ index_glycemic_load_dietary_carbohydrate_and_dietary_ fiber_intake_and_risk_of_liver_and_biliary_tract_cancers_in Western_Europeans>. doi: 10.1093/annonc/mds434.

2. Jomori MM, Proença RPC, Calvo MCM.Determinantes de escolha alimentar. Rev. Nutr., Campinas, v. 21, n. 1, Feb. 2008

3. Milagres MP, Minim VPR, Simiqueli AA, Espeschit CR, Minim LA. Fatores da embalagem de leite com concentração aumentada de melatonina na intenção de compra do consumidor. Rev. Inst. Laticínios CândidoTostes.[Internet]. 2014. [cited 2015 jan 06]; 69: 25-36. Available from:<http://www.revistadoilct.com. br/rilct/article/download/303/284>. doi: 10.14295/2238-6416. v69i1.303.

4. Monteiro MAM, Minim VPR, Silva AF, Chaves JBP. Influência da torra sobre a aceitação da bebida café. Rev. Ceres [Internet]. 2010 apr[cited 2015 aug 21]; 57( 2 ): 145-150. Available from:http:// www.scielo.br/scielo.php?script=sci_arttext\&pid=\$0034$737 \times 2010000200002 \&$ Ing=en. doi: 10.1590/S0034-737X2010 000200002

5. Vidigal MCTR, Minim VPR, Carvalho NB, Milagres MP, Gonçalves ACA. Effect of a health claim on consumer acceptance of exotic Brazilian fruit juices - Açaí (Euterpeoleracea Mart.), Camu-camu (Myrciariadubia), Caja (SpondiasLuteaL.) and Umbu (SpondiastuberosaArruda). Food Research International. [Internet].2011 [cited 2014 dec 02]; 44:1988-1996. Available from:<http://www.sciencedirect.com/science/article/pii/ S0963996910004618>. doi: 0.1016/j.foodres.2010.11.028.

6. Fazio RH, Sanbonmatsu DM, Powell MC, Kardes FR. On the automatic activation of attitudes. Journal of Personalityand Social Psychology.[Internet]. 1986. [cited 2014 nov 20];50 (2): 229-238.Available from:<http://www.ncbi.nlm.nih.gov/ pubmed/3701576>
7. Lalonde RN, Gardne RC. An inter group perspective on stereotype organization and processing. British Journal of Social Psychology.[Internet]. 1989. [cited 2014 nov20];28 (4): 289-303.Available from:<http://onlinelibrary.wiley.com/ doi/10.1111/j.2044-8309.1989.tb00872.x/abstract>doi: 10.1111/j.2044-8309.1989.tb00872.x.

8. Zarate MA, Smith ER. Person categorization and stereotyping. Social Cognition. [Internet]. 1990. [cited2014nov20];8(2):161-185. Available from: <http://guilfordjournals.com/doi/abs/10.1521/ soco.1990.8.2.161>. doi:10.1521/soco.1990.8.2.161.

9. Bargh JA, Chen M, Burrows L. Automaticity of social behavior: Direct effects of trait construct and stereotype activation on action. Journal of Personality and Social Psychology. [Internet]. 1996. [cited 2014 nov 20];171 (2): 230-244. Available from:<http://www.ncbi.nlm.nih.gov/pubmed/8765481>

10. Greenwald AG, Farnham SD. Using the Implicit Association Test to measure self-esteem and self-concept. Journal of Personalit yand Social Psychology.[Internet]. 2000.[cited 2014 nov 20];79 (6): 1022-1038. Available from:<http://psycnet.apa.org/ psycinfo/2000-16701-014>. doi: 10.1037/0022-3514.79.6.1022.

11. Greenwald AG, Mcghee DE, Schwartz JKL. Measuring individual differences in implicit cognition: The implicit association Test. Journal of Personality and Social Psychology. [Internet].1998. [cited 2014 sep 20]; 74 (6): 1464-1480. Available from:<http://www.ncbi.nlm.nih.gov/pubmed/9654756>. doi:10.1037/00223514.74.6.1464

12. Andrews JA, Hampson SE, Greenwald AG,Gordon J, Widdop C. Using the Implicit Association Test to Assess Children's Implicit Attitudes toward Somokin. J Appl Soc Psychol.[Internet]. 2010. [cited 2015 jan 20]; 40(9): 2387-2406. Available from:<http:// www.ncbi.nlm.nih.gov/pmc/articles/PMC3090631/>. doi: 10.1111/j.1559-1816.2010.00663.x.

13. Archana J, Earleywine M. Measuring alcohol expectancies with the implicit association test. Psychology of Addictive Behaviors. [Internet]. 2003. [cited 2014 nov 22]; 17 (2): 126-133. Available from: <http://www.ncbi.nlm.nih.gov/pubmed/12814276>

14. Maison D, Greenwald AG, Bruin R. Predictive validity of the Implicit Association Test in studies of brands, consumer attitudes, and behavior. Journal of Consumer Psychology. [Internet]. 2004. [cited 2014 nov 22];14(4): 405-41. Available from: <http://www.researchgate.net/publication/257474303_ Predictive_Validity_of_the_Implicit_Association_Test_in_ Studies_of_Brands_Consumer_Attitudes_and_Behavior>. doi: 10.1207/s15327663jcp1404_9.

15. Gouveia VV, Mendes LAC, Freire SEA, Freires LA, Barbosa LHGM. Medindo Associação Implícita com o FreelAT em Português: Um Exemplo com Atitudes Implícitas frente ao Poliamor. Psychology /PsicologiaReflexão e Crítica.[Internet]. 2014. [cited 2015 jan 06];27 (4): 679-688. Available from: <www.scielo.br/pdf/prc/ 
v27n4/0102-7972-prc-27-04-00679.pdf>. doi: 10.1590/16787153.201427408

16. Victoria MS, Fontenelle LF. O Teste de Associação Implícita no transtorno obsessivo-compulsivo (TAI-TOC): consistência interna e correlações com medidas explícitas. Rev. psiquiatr. clín. [Internet]. 2011. [cited 2014 dec 20] ; 38( 2 ): 53-56. Available from: <http://www.scielo.br/scielo.php?script=sci_ arttext\&pid=S0101-60832011000200002\&lng=en>. doi: 10.1590/S0101-60832011000200002

17. Greenwald AG, NosekBA,Banaji MR. Understanding and using the Implicit Association Test: I. An improveds coring algorithm. Journal of Personality and Social Psychology.[internet]. 2003. [cited 2014 dec 20]; 85, 197-216. Available from: <http:// faculty.washington.edu/agg/pdf/GB\&N.JPSP.2003.pdf>. doi:10.1037/0022-3514.85.2.197

18. Conselho Nacional de Saúde (Brasil). Resolução n o 466, de 12 de dezembro de 2012. Brasília, 2012 [cited 2014 ago 11]. Available from: <http://www.conselho.saude.gov.br/web_ comissoes/conep/index.html>.

19. Minim VPR. Análise Sensorial - Estudo com Consumidores. 3 ed. Viçosa, MG. Editora da Universidade Federal de Viçosa, 2013.

20. WagnerW, ValenciaJ, Elejabarrieta F. Relevance, discourse and the 'hot' stable core social representations-A structural analysis of word associations. British Journal of Social Psychology. [Internet]. 1996. [cited 2015 aug 15]; 35 (3): 331-351. Available from: <http://onlinelibrary.wiley.com/doi/10.1111/j.2044-8309.1996. tb01101.x/abstract;jsessionid=32E4D3F61D6F215E7DF56FEECB 1657E5.f01t02>doi: 10.1111/j.2044-8309.1996.tb01101.x.

21. Ares G, Giménez A, Gámbaro A. Understanding consumers perceptions of conventional and functional yogurts using word association and hardladdering. Food Quality and Preference. [Internet]. 2008. [cited 2015 jan 10]; 19 (7): 636-643. Available from: $\quad<h t t p: / / w w w . s c i e n c e d i r e c t . c o m / s c i e n c e / a r t i c l e / p i i /$ S0950329308000748> doi:10.1016/j.foodqual.2008.05.005.

22. Nosek BA, Greenwald AG, Banaji MR. Understanding and using the Implicit Association Test: II. Method variables and construct validity. Personality and Social Psychology Bulletin. [Internet]. 2005. [cited 2015 jan 10]; 31:166-180. Available from: <http://faculty.washington.edu/agg/pdf/NGB2005.PSPB. pdf >doi:10.1177/0146167204271418.

23. Nosek BA, Greenwald AG, Banaji MR. The Implicit Association Test at age 7: A methodological and conceptual review. In J. A. Bargh (Ed.), Automatic processes in social thinking and behavior (pp. 265-292). London: Psychology Press. 2007.

24. Alberti KG, ZimmetPz. Definition, diagnosis, and classification of diabetes mellitus and its complications. Part1: diagnosis and classification provisional report of WHO consultation. Diabet Med.[Internet]. 1998. [cited 2015 aug 10];15 (7):539-53. Available from: <http://www.ncbi.nlm.nih.gov/pubmed/9686693>

25. Sriram N, Greenwald AG. The brief Implicit Association Test. Experimental Psychology. [Internet]. 2009. [cited 2015 jan 10]; 56 (4): 283-294. Available from: <http://www.ncbi.nlm.nih.gov/ pubmed/19439401>doi:10.1027/1618-3169.56.4.283

26. Guimarães RR, Freitas MCJ, Silva VLM.Bolos simples elaborados com farinha da entrecasca de melancia (Citrullusvulgaris, sobral): avaliação química, física e sensorial. Ciênc. Tecnol. Aliment. [Internet]. 2010 [cited 2015 sep 15];30 (2): 354-363. Available from: <http://www.scielo.br/pdf/cta/v30n2/11.pdf>.

27.Milagres MP et al. Impacto da informação sobre a melatonina na aceitabilidade de leite. B. CEPPA. [Internet]. 2014 [cited 2014 dec 15];32 (1): 125-134.Available from: <http://ojs.c3sl.ufpr.br/ojs/ index.php/alimentos/article/view/36933>. doi: 10.5380/CEP. v32i1.36933.

28. Viana V. Psicologia, saúde e nutrição: Contributo para o estudo do comportamento alimentar. Análise Psicológica. [Internet]. 2002, [cited 2015 sep 20]; 4 (XX): 611-624. Available from: <http://publicacoes.ispa.pt/publicacoes/index.php/ap/article/ view/24/pdf>.

29. Gouveia VV et al. Introdução às Medidas Implícitas: conceitos, técnicas e contribuições. Revista da Sociedade de Psicologia do Rio Grande do Sul. [Internet]. 2012. [cited 2015 sep 15]; 12 (1): 80-92.Available from: <http://www.sprgs.org.br/diaphora/ojs/ index.php/diaphora/article/view/50/50>

30. Wijnkoop L, Jones PJ, Uauy R, Segal L, Milner J.Nutrition economics - food as an ally of public health. British Journal of Nutrition.[Internet].2013 [cited 2015 jan 06];109: 777784.Available from: <http://journals.cambridge.org/action/ displayAbstract? fromPage $=$ online $\&$ aid $=8850416 \&$ fileld $=$ S0007114512005107> . doi: 10.1017/S0007114512005107.

31. Barreto MS, Passos VMA,Giattil L. Comportamento saudável entre adultos jovens no Brasil. Rev Saúde Pública. [Internet]. 2009. [cited 2015 sep 15]; 43(2): 9-17. Available from: < http:// www.scielo.br/pdf/rsp/v43s2/ao799.pdf>.

32. Vicente FR, Santos SMA. Avaliação multidimensional dos determinantes do envelhecimento ativo em idosos de um município de Santa Catarina. Texto Contexto Enfer. [Internet]. 2013. [cited 2015 oct 20]; 22(2): 370-8. Available from: <http:// www.scielo.br/pdf/tce/v22n2/v22n2a13.pdf>

33. Zakir MM, Freitas IR. Benefícios à saúde humana do consumo de isoflavonas presentes em produtos derivados da soja. J. Bioen. FoodSci. [Internet]. 2015. [cited 2015 oct 20]; 2 (3): 107-116. Available from: <http://periodicos.ifap.edu.br/index.php/JBFS/ article/view/50/68>. doi: 10.18607/jbfs.v2i3.50.

34. Bendino NI, Popolim WD, Oliveira CRA.Avaliação do conhecimento e dificuldades de consumidores frequentadores de supermercado convencional em relação rotulagem de alimentos 
e informação nutricional. J Health Sci Inst. [Internet]. 2012 [cited 2015 sep 15]; 30 (3): 261-265.Available from: <http://www3. unip.br/comunicacao/publicacoes/ics/edicoes/2012/03_jul-set/ V30_n3_2012_p261a265.pdf>.

35. Garcia PPC, Carvalho LPS. Análise da rotulagem nutricional de alimentos diet e light. Ensaios e Ciência: Ciências Biológicas, Agrárias e da Saúde. [Internet]. 2011 [cited 2015 sep 15]; 15(4): 89-103.Available from: <http://www.redalyc.org/articulo. oa?id=26022135007 >.

36. ZagoAG, Rossi DA. Avaliação dos itens obrigatórios na rotulagem nutricional de produtos lácteos fermentados. Rev. Inst. Adolfo Lutz (Impr.) [periódico na Internet]. 2010 [cited2015 oct 14] ; 69(1): 62-68. Available from: <http://periodicos. ses.sp.bvs.br/scielo.php?script=sci_arttext $\&$ pid=S007398552010000100009\&lng=pt>

Publish in International Archives of Medicine

International Archives of Medicine is an open access journal publishing articles encompassing all aspects of medical science and clinical practice. IAM is considered a megajournal with independent sections on all areas of medicine. IAM is a really international journal with authors and board members from all around the world. The journal is widely indexed and classified Q2 in category Medicine. 